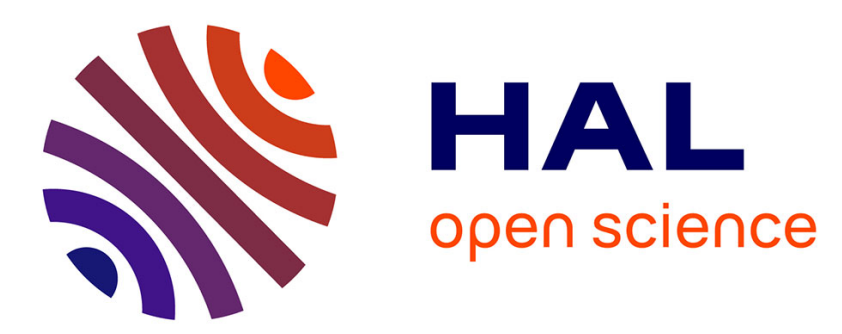

\title{
Diselenolene proligands: reactivity and comparison with their dithiolene congeners
}

Yann Le Gal, Thierry Roisnel, F Barriere, Takehiko Mori, Dominique Lorcy

\section{To cite this version:}

Yann Le Gal, Thierry Roisnel, F Barriere, Takehiko Mori, Dominique Lorcy. Diselenolene proligands: reactivity and comparison with their dithiolene congeners. New Journal of Chemistry, 2021, 45 (20), pp.8971-8977. 10.1039/d1nj01335a . hal-03245157

\section{HAL Id: hal-03245157 \\ https://hal.science/hal-03245157}

Submitted on 18 Jun 2021

HAL is a multi-disciplinary open access archive for the deposit and dissemination of scientific research documents, whether they are published or not. The documents may come from teaching and research institutions in France or abroad, or from public or private research centers.
L'archive ouverte pluridisciplinaire HAL, est destinée au dépôt et à la diffusion de documents scientifiques de niveau recherche, publiés ou non, émanant des établissements d'enseignement et de recherche français ou étrangers, des laboratoires publics ou privés. 


\title{
Diselenolene proligands:
}

\section{reactivity and comparison with their dithiolene congeners}

Yann Le Gal, ${ }^{\mathrm{a}}$ Thierry Roisnel, ${ }^{\mathrm{a}}$ Frédéric Barrière, ${ }^{\mathrm{a}}$ Takehiko Mori, ${ }^{\mathrm{b}}$ Dominique Lorcy ${ }^{\mathrm{a}}$

a-Univ Rennes, CNRS, ISCR (Institut des Sciences Chimiques de Rennes)-UMR 6226, F-35000 Rennes, France.

$b$-Department of Materials Science and Engineering, Tokyo Institute of Technology, $O$ okayama 2-12-1, Meguro-ku, 152-8552, Japan.

\begin{abstract}
The reactivity of various diselenolene proligands shows some discrepancies compared to that of the dithiolene analogues, leading essentially to the formation of selenophene and diselenine derivatives rather than the planar selenated $\pi$-electron acceptor. Furthermore, chalcogen $\bullet \bullet$ chalcogen bonding interactions have been evidenced by X-ray diffraction study of the electroactive diselenine, the diselenine bridge acting as chalcogen bond donors towards the thione $(\mathrm{C}=\mathrm{S})$ chalcogen bond acceptors.
\end{abstract}

Keywords: selenophene, diselenine, dithiolene ligand, diselenolene ligand, electron acceptor

$\dagger$ Electronic supplementary information (ESI) available. CCDC 2063244-2063245 and Cyclic voltammogram of diselenine 7 and SS-Et. For ESI and crystallographic data in CIF or other electronic format see DOI: XXXXX

\section{Introduction}

The design and synthesis of organic $\pi$-electron acceptors for the elaboration of organic materials is receiving considerable attention due to their applications in electronic and optoelectronic devices. ${ }^{1}$ For instance, materials performance improvements have been observed in the field of 
n-type organic field effect transistor (OFET) thanks to the design of acceptors with appropriate energy levels. ${ }^{2}$ In this context, we investigated the synthesis of planar sulfur rich electron acceptors such as SS-R (Chart 1$)^{3}$ and showed that the presence of the sulfur atoms has a significant and favorable influence on the air stability of n-channel OFET. ${ }^{4,5}$ Substitution strategies to increase the intermolecular interactions have often been used in molecular conductors, as for example the introduction of heavier selenium atoms instead of sulfur. The S/Se substitution usually increases intermolecular interactions and consequently band dispersions in the solid state, responsible for the formation of highly conducting systems. ${ }^{6}$ However, even if some similarities exist between organoselenium and organosulfur chemistry, some discrepancies can be noticed especially due to the weaker Se-C bond and the facile oxidation of divalent selenium derivatives. ${ }^{7}$ In order to prepare the sulfur-rich substituted SS-R acceptors, we have developed and reported different chemical routes, starting from either organic or inorganic protected forms of dithiolene ligands. ${ }^{8}$ It is worth mentioning that during our investigations on the reactivity of dithiolene proligands with a thiazoline-2-thione backbone where $\mathrm{R}=\mathrm{CH}\left(\mathrm{CH}_{3}\right) \mathrm{C}_{6} \mathrm{H}_{4}$ (Chart 1), we did not form the planar SS-R acceptor but isolated an electroactive 1,2-dithiine acceptor. ${ }^{9}$ The formation of this dithiine was reminiscent to the study carried out by Rauchfuss et al. who generated the 1,2-dithiine tricyclic structure $\mathrm{C}_{6} \mathrm{~S}_{8}$ from the 2-thioxo-1,3-dithiol-4,5-dithiolene ligand. ${ }^{10}$ Diselenolene proligands are also easily accessible and we thus wanted to test their ability to form selenium substituted acceptors, analogues of the all-sulfur based SS-R or dithiine with respectively two sulfur atoms replaced by two selenium atoms in SSe-Et or in a tricyclic diselenine, Chart 1.

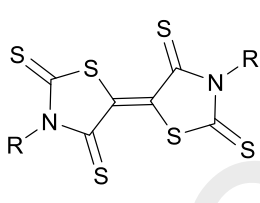

SS-R

$\mathrm{R}=\mathrm{Me}, \mathrm{Et}, \mathrm{EtOH}, \mathrm{Pr}$

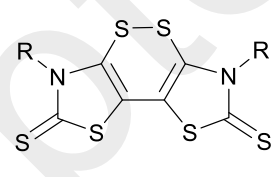

dithiine $\mathrm{R}=\mathrm{CHCH}_{3} \mathrm{C}_{6} \mathrm{H}_{5}$
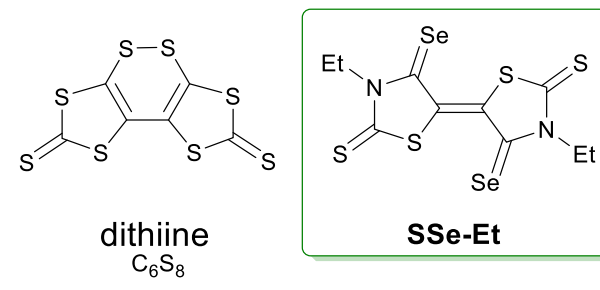

\section{Chart 1}

Herein we describe our investigations on the reactivity of various diselenolene proligands with a N-Et-1,3-thiazoline-2-thione backbone, in analogy with our previous works on dithiolene proligands. We show that replacing sulfur with selenium atoms did not afford the anticipated planar SSe-Et acceptor but rather selenophene or diselenine derivatives. 


\section{Results and discussion}

As shown in Scheme 1, the all-sulfur acceptor SS-Et has been formed by different routes, all starting from a N-Et-1,3-thiazoline-2-thione dithiolene ligand protected either with an organic group or as a metallic complex. ${ }^{8}$ In order to investigate the reactivity of the corresponding diselenolene derivatives, four diselenolene proligands were first synthetized as described in Scheme 2.

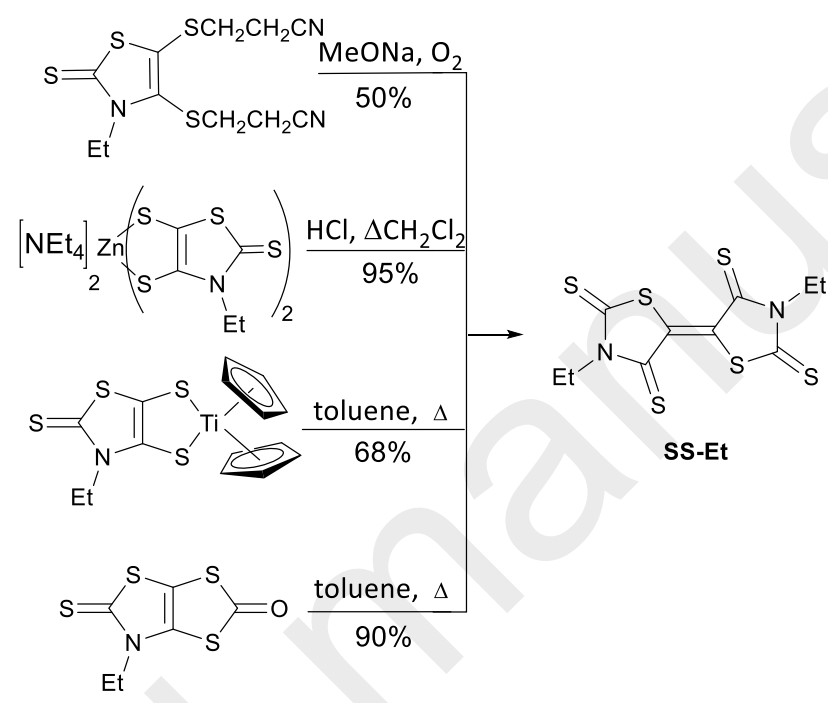

Scheme 1 Comparison of the efficiency of the different synthetic routes towards SS-Et starting from different various proligands

N-ethyl-1,3-thiazoline-2-thione 1 was used as starting material for the preparation of either the organic protected ligand, such as the bis(cyanoethylseleno) derivative ${ }^{6} \mathbf{2}$ or the diselenolene-2-one compound $\mathbf{3}$, or the inorganic protected form, such as the bis(cyclopentadienyl)Ti(diselenolene) complex $\mathbf{4}$ or the dianionic $\mathrm{Zn}$ bis(diselenolene) complex 5 (Scheme 2). For that purpose, we prepared the proligands 2-4 according to the same sequence: first, addition of LDA and selenium powder to afford the corresponding diselenolate that is then reacted with bromopropionitrile to afford $\mathbf{2}^{6}$, or with triphosgene to generate $\mathbf{3}$, or with $\mathrm{Cp}_{2} \mathrm{TiCl}_{2}$ to give the corresponding Ti complex 4. For the synthesis of the $\mathrm{Zn}$ complex $\mathbf{5}$, we used the proligand $\mathbf{2}$. After the regeneration of the diselenolene ligand through the addition of $\mathrm{NaOMe}$ in the medium, $\mathrm{ZnCl}_{2}$ and $\mathrm{NEt}_{4} \mathrm{Br}$ were successively added to afford the corresponding proligand $\mathbf{5}$. We also prepared the diselenone $\mathbf{3}$ by simply heating a solution of the $\mathrm{Cp}_{2} \mathrm{Ti}$ complex 4 in THF in the presence of triphosgene or by deprotection of the proligand 
2 with a solution of LDA followed by an addition of triphosgene (Scheme 2). Using one or the other approaches, we noticed a degradation of the bicyclic structure during the work up and purification of the diselenone $\mathbf{3}$. Therefore $\mathbf{3}$ was used in the next step as a crude product. ${ }^{11}$

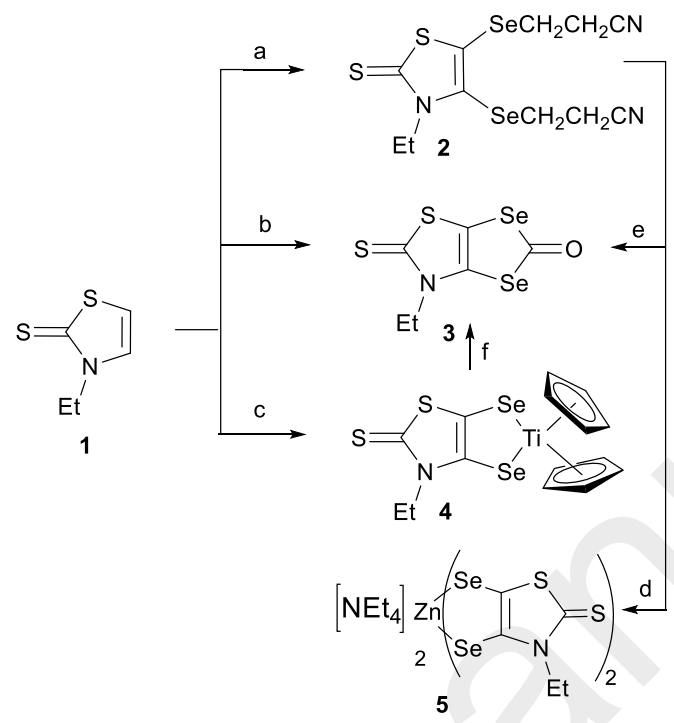

Scheme 2 Synthesis of the different diselenolene proligands 2-5. Reagents and conditions: (a) LDA, Se, $\mathrm{BrCH}_{2} \mathrm{CH}_{2} \mathrm{CN}$, (b) LDA, Se $\left(\mathrm{Cl}_{3} \mathrm{CO}\right)_{2} \mathrm{CO}$, (c) LDA, Se, $\mathrm{Cp}_{2} \mathrm{TiCl}_{2}$, (d) $\mathrm{MeONa}, \mathrm{ZnCl}_{2}, \mathrm{NEt}_{4} \mathrm{Br}$. Alternative routes to $\mathbf{3}$ from proligands $\mathbf{2}$ and $\mathbf{4}$. Reagents and conditions: (e) LDA, $\left(\mathrm{Cl}_{3} \mathrm{CO}\right)_{2} \mathrm{CO}$, (f) $\left(\mathrm{Cl}_{3} \mathrm{CO}\right)_{2} \mathrm{CO}, \mathrm{THF}, \Delta$.

Having in hands these four diselenolene proligands $\mathbf{2 - 5}$, we studied their reactivity toward the formation of the SSe-Et acceptor or diselenine structure, in analogy with our previous investigations on dithiolene proligands. ${ }^{8}$ First of all we attempted the aerial oxidation of the diselenolate, generated from the bis(cyanoethylseleno)-1,3-thiazoline-2-thione 2 with an excess of $\mathrm{NaOMe}$. However, using this procedure, we were not able to isolate any acceptor. On the other hand, the thermal treatment in refluxing toluene of the diselenone 3 under inert atmosphere leads to the formation of a novel compound. After the usual work up, we isolated crystals by slow concentration of a $\mathrm{CH}_{2} \mathrm{Cl}_{2}$ solution, and performed an $\mathrm{X}$-ray structure determination. As shown in Fig. 1, it turns out that the compound formed in the medium in 57 $\%$ yield is the selenophene 6 (Scheme 3 ). 


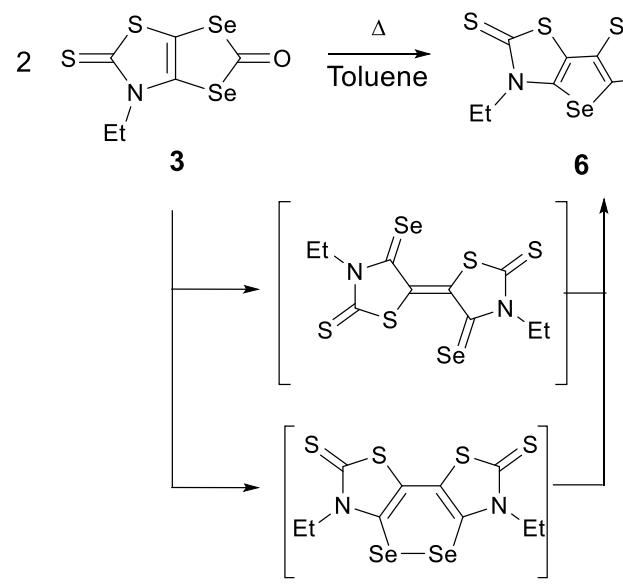

Scheme 3 Synthesis of selenophene 6 through thermal treatment of $\mathbf{3}$

Compound 6 crystallizes in the monoclinic system, space group P2 $2 / c$. As observed in Fig. 1, the selenophene derivative $\mathbf{6}$ is quasi-planar with the ethyl substituents on the nitrogen, pointing above and below the plane.
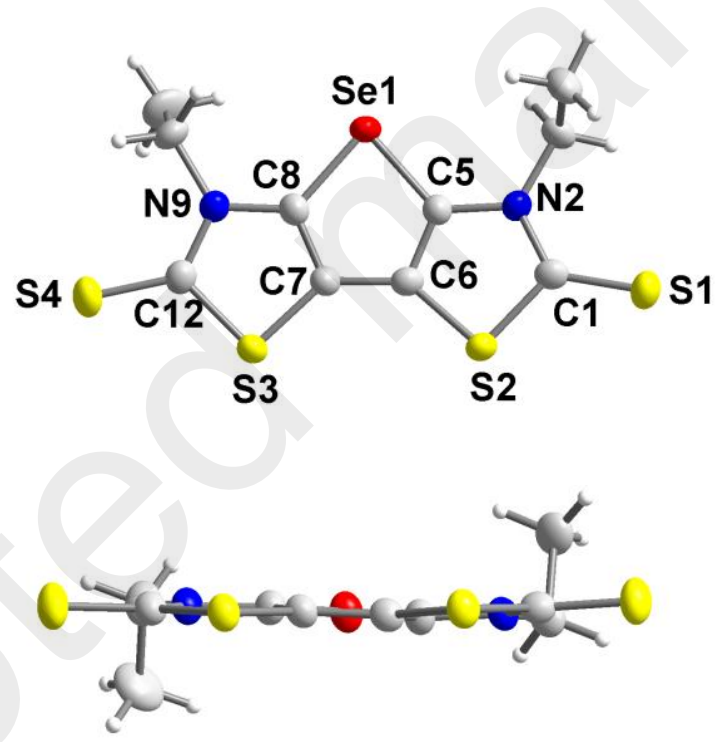

Fig. 1 Molecular structure of selenophene 6 (top) and side view (bottom). Thermal ellipsoids are drawn at the $80 \%$ probability level.

A plausible explanation for the formation of the selenophene 6 is shown in Scheme 3. During the thermal treatment of the diselenolone 3, either the SSe-Et or a cyclic diselenine is formed which probably undergoes a thermal deselenation to form the selenophene $6 .{ }^{12}$ This thermal Se extrusion is similar to that described by Schroth et al in the thermal treatment of dithiines in DMSO to afford thiophenes. ${ }^{13}$ The involvement of these proposed intermediates is supported by our previous observations of the reactivity of different sulfur analogues (Scheme 
4), where the thermal treatment of various dithiol-2-ones led essentially to the acceptors SS$\mathrm{R},{ }^{8,14}$ while the dithiine was isolated only in one case with $\mathrm{R}=\mathrm{CH}\left(\mathrm{CH}_{3}\right) \mathrm{C}_{6} \mathrm{H}_{4} .{ }^{9}$ In the literature however, the transformation of a diselenine into a selenophene is usually performed at higher temperatures in the presence of copper metal. ${ }^{15}$

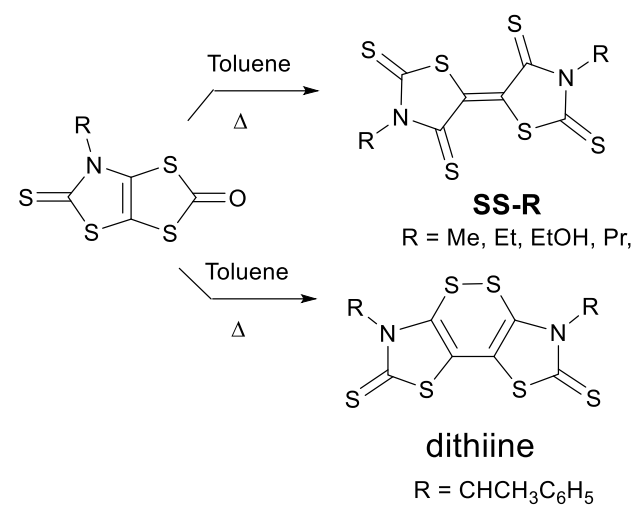

Scheme 4 Synthesis of either SS-R or dithiine

We also studied the reactivity of the inorganic protected forms of the diselenolene ligands, i.e. 4 and 5. The thermal treatment of $\mathrm{Cp}_{2} \mathrm{Ti}(\mathrm{Et}$-thiazds) 4 in boiling toluene does not lead, as in the dithiolene series, to the formation of the acceptor, neither to the selenophene $\mathbf{6}$, but rather to degradation products. We thus performed the reaction in milder conditions. Decoordination of the $\mathrm{Cp}_{2} \mathrm{Ti}$ protecting group was performed after 4 days at $35{ }^{\circ} \mathrm{C}$ in $\mathrm{CH}_{2} \mathrm{Cl}_{2}$ /THF in the presence of a large excess of $\mathrm{NaCl}$ together with silica gel. Under these conditions, we isolated a compound corresponding to the diselenine 7 in $46 \%$ yield (Scheme 5). Crystals were obtained by slow concentration of a dichloromethane solution of 7 and were analyzed by X-ray diffraction.

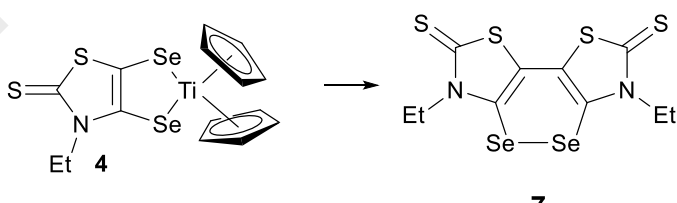

Scheme 5 Synthesis of diselenine 7 from the proligand 4. Reagents and conditions : $\mathrm{NaCl}, \mathrm{CH}_{2} \mathrm{Cl}_{2} / \mathrm{THF}, 35^{\circ} \mathrm{C}$ for 4 days.

The molecular structure of $\mathbf{7}$ is given in Fig. 2. Compound $\mathbf{7}$ crystallizes in the monoclinic system, space group $P 2{ }_{1} / n$. The six-membered heterocyclic ring with a diselenide bridge is twisted, with a $\mathrm{C}-\mathrm{Se}-\mathrm{Se}-\mathrm{C}$ torsion angle of $57.06^{\circ}$. As a consequence, the two thiazole 
rings are not coplanar and form a dihedral angle of $37.06^{\circ}$, while the Se-Se bond length amounts to 2.3620 (4) $\AA$. These structural parameters are in the range observed earlier for diselenine derivatives. ${ }^{16}$
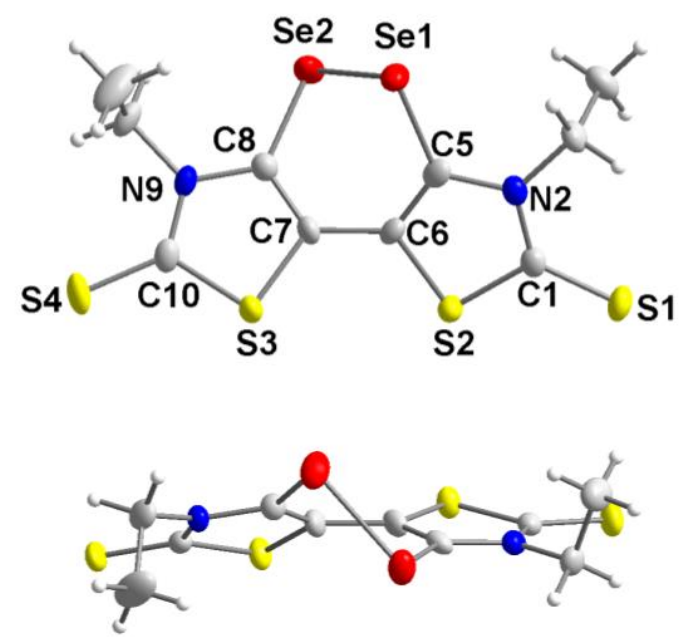

Fig. 2 Molecular structure (top) and side view (bottom) of diselenine 7. Ellipsoids are drawn at $80 \%$ probability.

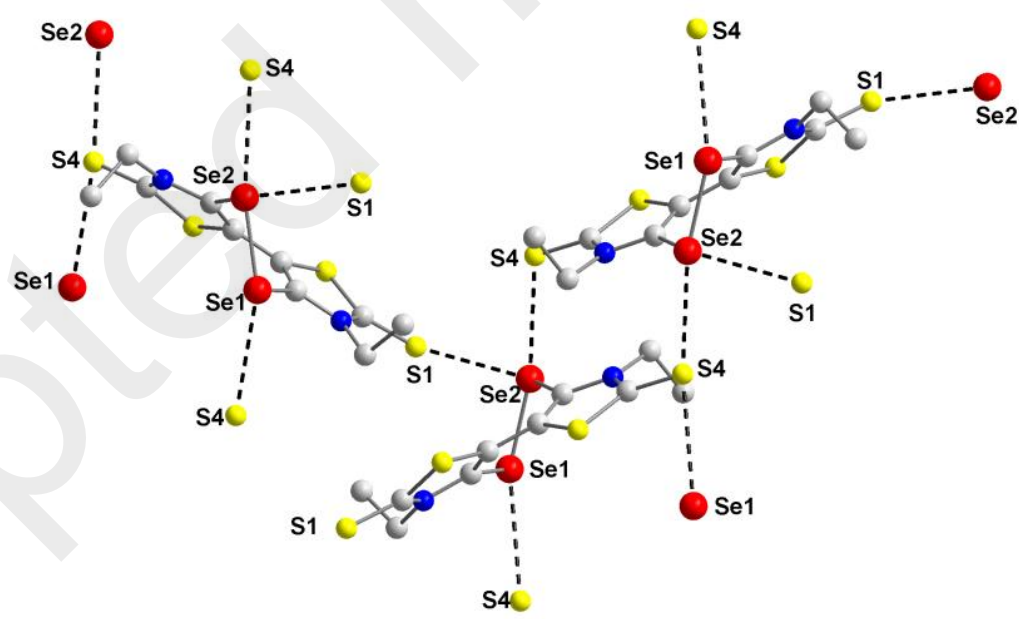

Fig. 3 Details of the shortest Se••s interaction network in 7

Investigation of the intermolecular distances shows the existence of short Se••s contacts between the selenium atoms of one molecule and the exocyclic sulfur atoms of neighboring molecules (Fig. 3) with the shortest interatomic distances at 3.3120(6) $\AA$ for Se2*•.S4, $3.4768(8)$ for $\mathrm{Se} 2 \bullet \bullet \mathrm{S} 1$ and $3.4893(7) \AA$ for $\mathrm{Se} 1 \bullet \bullet S 4$, that correspond to a reduction ratio of 
$89.5 \%, 93.9 \%$ and $94.3 \%$ respectively relative to the van der Waals contact distance (Se•••S : $3.70 \AA)$.

In order to gain a bettter understanding and to rationalize these solid state interactions, we performed electrostatic surface potential calculations on the optimized geometry of 7. Indeed within organic diselenides, four charge depleted areas should be observed, two located in the prolongation of the $\mathrm{C}$-Se bonds and two in the prolongation of the Se-Se bond. ${ }^{17,18}$ As shown in Figure 3, four positive maxima are indeed found, two in a spreaded positive area between

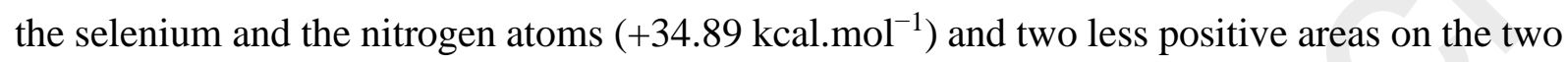
selenium atoms $\left(+28.99 \mathrm{kcal}^{\mathrm{mol}} \mathrm{m}^{-1}\right)$ in the prolongation of the C-Se bonds. The most negative extrema are found on the exocyclic sulfur atoms belonging to the thiocarbonyl groups $(-25.95$ kcal.mol ${ }^{-1}$ ). This calculated charge repartition is in good agreement with the structural organization of molecule 7 (Fig. 4), which places the electron rich sulfur atoms in close proximity to the electron depleted area around the diselenine bridge. Such a polarization pattern allows us to describe these short contacts as two chalcogen bond interactions. ${ }^{19}$

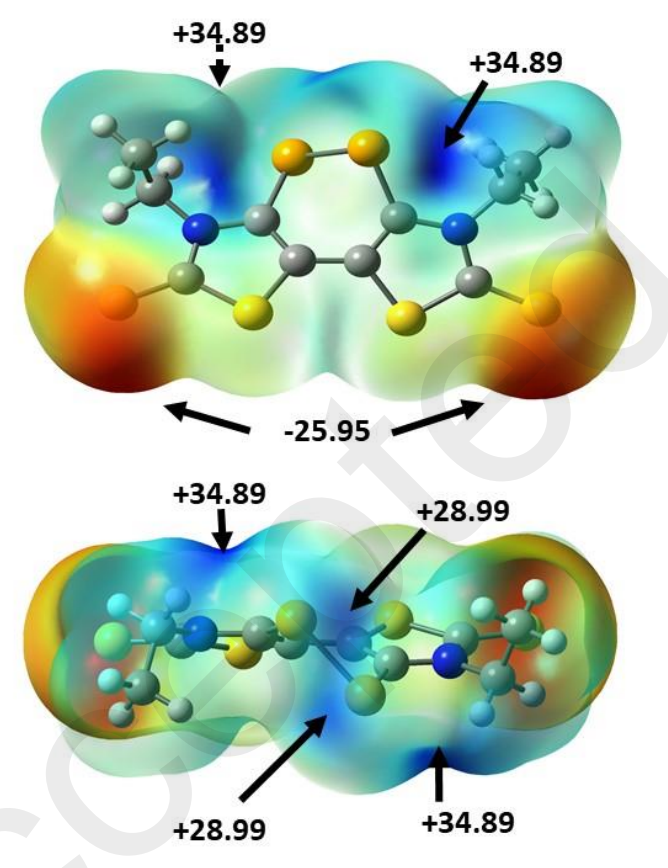

Fig. 4 Molecular electrostatic potential surfaces mapped at $0.001 \mathrm{e}^{-} \cdot \mathrm{au}^{-3}$ isodensity surface for 7. The common color scale ranges from $-26 \mathrm{kcal}_{\mathrm{mol}}{ }^{-1}$ (red) to $+35 \mathrm{kcal} \cdot \mathrm{mol}^{-1}$ (blue).

DFT calculations [Gaussian03, B3LYP/6-31+G**] were carried out on the neutral diselenine 7. Full geometry optimizations led to the molecular structure depicted in Fig. 4. The optimized 
geometry of $\mathbf{7}$ is in very good agreement regarding bond angles and bond lengths, with the experimental one obtained by X-ray diffraction. The HOMO of 7 is essentially localized on the two thiazoline-2-thione rings while the LUMO is predominantly localized on the diselenine bridge with some contribution found on the $\mathrm{C}-\mathrm{C}$ bond connecting the two thiazoline rings.

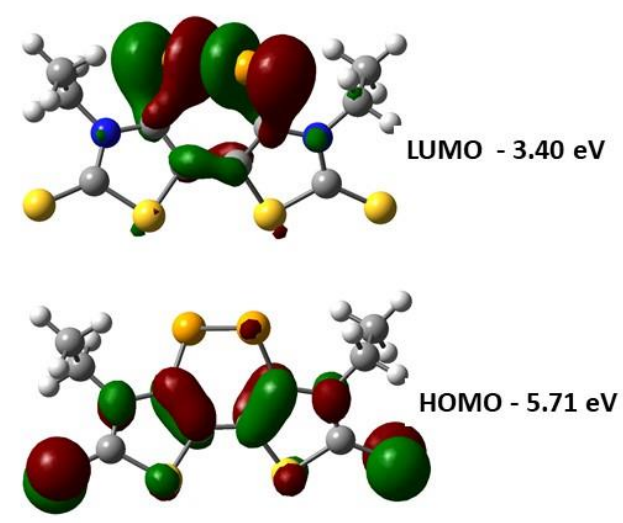

Fig. 5 HOMO and LUMO of diselenine 7 shown with a cut-off of $0.04\left[\mathrm{e} / \mathrm{bohr}^{3}\right]^{1 / 2}$.

As shown in Figure 5 the energy of the LUMO of diselenine 7 is located at $-3.40 \mathrm{eV}$ while that of the all-sulfur analogue, SS-Et, is well below $-4.0 \mathrm{eV}(-4.22 \mathrm{eV})^{3}$ indicating a weaker acceptor ability of the diselenine 7 . This was confirmed by cyclic voltammetry experiments performed in $\mathrm{CH}_{2} \mathrm{Cl}_{2}$ with $\mathrm{Bu}_{4} \mathrm{NPF}_{6}$ as supporting electrolyte for both derivatives. The reduction processes for 7 occur at $E_{1}=-0.31 \mathrm{~V}$ and $E_{2}=-0.64 V$ while $S S-E^{3}$ is reduced at $E_{1}=-0.05 V$ and $E_{2}=-$ 0.44 V (vs. SCE, Fig. S1 see ESI).

We also investigated the reactivity of the $\mathrm{Zn}$ bis(diselenolene) complex $\mathbf{5}$ in acidic media as this pathway allowed us to form the SS-Et acceptor from the corresponding dithiolene complex. It is worth mentioning that this approach afforded also the dithiine in two cases, from the thermal decomposition of $\left[\mathrm{Zn}(\mathrm{dmit})_{2}\right]_{2}$ in the presence of $\mathrm{HCl}^{10}$ and with a similar treatment on $\left[\mathrm{NEt}_{4}\right]_{2}\left[\mathrm{Zn}\left(\mathrm{C}_{6} \mathrm{H}_{5}\left(\mathrm{CH}_{3}\right) \mathrm{CH}\right.\right.$-thiazdt $\left.)\right] .{ }^{9}$ By heating the zinc salt 5 in $\mathrm{CH}_{2} \mathrm{Cl}_{2}$ in the presence of $\mathrm{HCl}$ we did not observe the formation of either the diselenine or the SSe-Et acceptor but isolated instead the thiazoline-2 thione 1. As the proposed mechanism for the formation of the SS-Et acceptor from the dithiolene was an oxidation of the ligand, we simply tried an electrocrystallisation of $\mathbf{5}$ using $\mathrm{NH}_{4} \mathrm{PF}_{6}$ as supporting electrolyte. After a couple of days at room temperature, crystals of the diselenine 7 were collected at the anode upon application of a direct current of $1 \mu \mathrm{A}$ intensity (Scheme 6). 


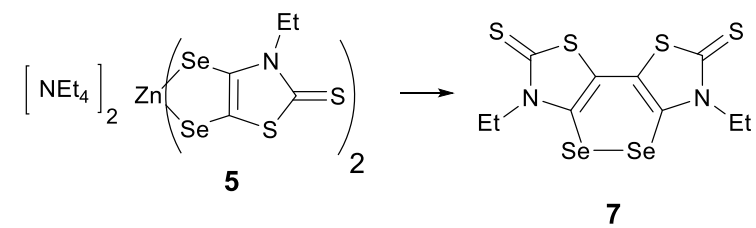

Scheme $\mathbf{6}$ Synthesis of diselenine $\mathbf{7}$ from the proligand $\mathbf{5}$. Reagents and conditions : electrocrystallization

Having in hands the diselenine 7, in order to determine if this compound was an intermediate in the formation of the selenophene $\mathbf{6}$ when heating 3 into toluene, we attempted to convert 7 into 6 by simply heating 7 in refluxing toluene. However after several attempts we did not evidence the formation of the selenophene $\mathbf{6}$ in the medium indicating that the formation of selenophene $\mathbf{6}$ from $\mathbf{3}$ is rather due to the formation of the acceptor SSe-Et as an intermediate (Scheme 3).

\section{Conclusion}

The synthesis of various protected diselenolene ligands has been performed with the aim of gaining access to the corresponding acceptor the 3,3'-diethyl-5,5'-bithiazolidinylidene-2,2' 4,4'-tetrachalcogenone, SSe-Et. The reactivity of these diselenolene proligands has been investigated in the same experimental conditions as those used for the dithiolene proligands analogues. Interestingly, using the diselenol-2-one, as protecting group of the diselenolene ligand, the selenophene was mainly formed in refluxing toluene, while the dithiole-2-one proligand, in the same conditions, led to the SS-Et acceptor. Similarly using the inorganic form of the diselenolene proligand the diselenine was isolated while for the same protecting group of the dithiolene ligand the SS-Et acceptor was also isolated. The diselenine is an electroactive molecule which can be reversibly reduced to the radical anion and the dianion. As demonstrated through X-ray diffraction analyses and confirmed with the calculated electrostatic surface potential maxima, the diselenine bridge can act as chalcogen bond donors towards the exocyclic sulfur atoms of the thione $(\mathrm{C}=\mathrm{S})$ acting as chalcogen bond acceptors. This opens the way to further investigate the metal complexation properties of this redox active diselenine ligand. ${ }^{20}$ 


\section{Experimental section}

All commercial chemicals were used without further purification. All the NMR spectra were obtained in $\mathrm{CDCl}_{3}$ unless indicated otherwise. Chemical shifts are reported in ppm and ${ }^{1} \mathrm{H}$ NMR spectra were referenced to residual $\mathrm{CHCl}_{3}(7.26 \mathrm{ppm})$ or DMSO $(2.50 \mathrm{ppm})$ and ${ }^{13} \mathrm{C} \mathrm{NMR}$ spectra were referenced to $\mathrm{CHCl}_{3}(77.2 \mathrm{ppm})$ or DMSO $(39.5 \mathrm{ppm})$. Melting points were measured on a Kofler hot-stage apparatus and are uncorrected. Mass spectra were recorded with Waters Q-Tof 2 instrument by the Centre Régional de Mesures Physiques de l'Ouest, Rennes. Elemental analyses were performed at the Centre Régional de Mesures Physiques de l'Ouest, Rennes. Column chromatography was performed using silica gel Merck 60 (70-260 mesh). All reagents and materials from commercial sources were used without further purification. The thiazoline derivative 2 was prepared according to literature procedure. ${ }^{6}$ Elemental analyses for $\mathbf{3}$ and $\mathbf{7}$ were not performed due to high sensitivity towards temperature during recrystallization and to the small amounts of crystals obtained, respectively.

\section{Synthesis of diselenone-1,3-thiazoline-2-thione 3.}

From 1 :To a $-10^{\circ} \mathrm{C}$ cooled solution of thiazoline $1(500 \mathrm{mg}, 3.44 \mathrm{mmol})$ in $40 \mathrm{~mL}$ of dry THF under nitrogen was added a solution of LDA prepared from diisopropylamine $(0.75 \mathrm{~mL}, 5.3$ $\mathrm{mmol}$ ) and $\mathrm{n}$-BuLi $1.6 \mathrm{M}$ in hexane $(3.2 \mathrm{~mL}, 5.3 \mathrm{mmol})$ in $10 \mathrm{ml}$ of dry THF. After stirring for $30 \mathrm{~min}$ at $-10^{\circ} \mathrm{C}$, selenium $(418 \mathrm{mg}, 5.3 \mathrm{mmol})$ was added and the solution was stirred for an additional $30 \mathrm{~min}$. A solution of LDA (diisopropylamine $1.00 \mathrm{~mL}, 7.0 \mathrm{mmol}$ and n-BuLi 1.6 M in hexane $4.30 \mathrm{~mL}, 7.0 \mathrm{mmol}$ ) in $15 \mathrm{~mL}$ of dry THF was added. The mixture was stirred for 3 hours and selenium $(552 \mathrm{mg}, 7.0 \mathrm{mmol})$ was added. After $30 \mathrm{~min}$ triphosgene $(2.06 \mathrm{~g}, 6.9 \mathrm{mmol})$ was added. The reaction mixture was stirred overnight and water $(50 \mathrm{~mL})$ was slowly added. The solvent was evaporated in vacuo. Dichloromethane $(50 \mathrm{~mL})$ was added and the organic phase was washed with water $(3 \times 20 \mathrm{~mL})$ and dried over $\mathrm{MgSO}_{4}$.

From 2 : To a $-10^{\circ} \mathrm{C}$ cooled solution of $2(200 \mathrm{mg}, 0.49 \mathrm{mmol})$ in $50 \mathrm{~mL}$ of dry THF under nitrogen was added a solution of LDA prepared from diisopropylamine $(0.15 \mathrm{~mL}, 1.1 \mathrm{mmol})$ and $\mathrm{n}$-BuLi 1.6 M in hexane $(0.67 \mathrm{~mL}, 1.1 \mathrm{mmol})$ in $20 \mathrm{ml}$ of dry THF. After stirring for 30 min at $-10^{\circ} \mathrm{C}$ the reaction mixture was cooled to $-20^{\circ} \mathrm{C}$ and triphosgene $(160 \mathrm{mg}, 0.54 \mathrm{mmol})$ was added. The reaction mixture was stirred at room temperature overnight, cooled to $-20^{\circ} \mathrm{C}$ and water $(50 \mathrm{~mL})$ was slowly added. The solvent was evaporated in vacuo and dichloromethane $(80 \mathrm{~mL})$ was added. The organic phase was washed with water $(2 \times 30 \mathrm{~mL})$ and dried over $\mathrm{MgSO}_{4}$. 
From 4: To a solution of titanium complex 4 (100 mg, $0.23 \mathrm{mmol})$ in $20 \mathrm{~mL}$ of dry THF under nitrogen was added triphosgen $(137 \mathrm{mg}, 0.46 \mathrm{mmol})$. The mixture was refluxed 25 minutes, cooled at $0^{\circ}$ and water $(10 \mathrm{~mL})$ was slowly added. The solvent was evaporated in vacuo and dichloromethane $(80 \mathrm{~mL})$ was added. The organic phase was washed with water $(2 \times 30 \mathrm{~mL})$ and dried over $\mathrm{MgSO}_{4}$. Attempts to purify 3 lead to degradation product, thus $\mathbf{3}$ was used in the next step without further purification. ${ }^{1} \mathrm{H} \mathrm{NMR}(300 \mathrm{MHz}) \delta 1.36\left(\mathrm{t}, 3 \mathrm{H}, \mathrm{CH}_{3},{ }^{3} \mathrm{~J}=7.0 \mathrm{~Hz}\right)$, $4.56\left(\mathrm{~m}, 2 \mathrm{H}, \mathrm{CH}_{2}\right)$; IR $v_{\mathrm{C}=\mathrm{S}}=1347 \mathrm{~cm}^{-1}$.

Cp2Ti(Et-thiazds) 4: To a $-10^{\circ} \mathrm{C}$ cooled solution of N-Et-1,3-thiazoline-2-thione 1 $(1.45 \mathrm{~g}, 10.0 \mathrm{mmol})$ in $50 \mathrm{~mL}$ of dry THF under nitrogen was added a solution of LDA prepared from diisopropylamine $(2.1 \mathrm{~mL}, 15.0 \mathrm{mmol})$ and $\mathrm{n}-\mathrm{BuLi} 1.6 \mathrm{M}$ in hexane $(9.4 \mathrm{~mL}, 15.0 \mathrm{mmol})$ in $20 \mathrm{ml}$ of dry THF. After stirring for $30 \mathrm{~min}$ at $-10^{\circ} \mathrm{C}$, selenium $(1.12 \mathrm{~g}, 15.0 \mathrm{mmol})$ was added and the solution was stirred for an additional $30 \mathrm{~min}$. A solution of LDA prepared from diisopropylamine $(2.8 \mathrm{~mL}, 20.0 \mathrm{mmol})$ and $\mathrm{n}-\mathrm{BuLi} 1.6 \mathrm{M}$ in hexane $(12.5 \mathrm{~mL}, 20.0 \mathrm{mmol})$ in $30 \mathrm{~mL}$ of dry THF was added. The mixture was stirred for 3 hours and selenium (1.58 g, 20.0 mmol) was added. After $30 \mathrm{~min} \mathrm{TiCp}_{2} \mathrm{Cl}_{2}(2.74 \mathrm{~g}, 11.0 \mathrm{mmol})$ was added. The reaction mixture was stirred $1 \mathrm{~h}$. The solvent was evaporated in vacuo. The concentrated solution was purified by chromatography on silica gel using $\mathrm{CH}_{2} \mathrm{Cl}_{2}$ as eluent to afford 4 as a blue-green powder. Yield : $62 \% . \mathrm{Mp}>260^{\circ} \mathrm{C} ; \mathrm{R}_{f}=0.73\left(\mathrm{SiO}_{2}, \mathrm{CH}_{2} \mathrm{Cl}_{2}\right){ }^{1} \mathrm{H} \mathrm{NMR}(300 \mathrm{MHz}) \delta 1.39\left(\mathrm{t}, 3 \mathrm{H}, \mathrm{CH}_{3},{ }^{3} J\right.$ $=7.0 \mathrm{~Hz}), 4.54\left(\mathrm{~m}, 2 \mathrm{H}, \mathrm{CH}_{2}\right), 5.64(\mathrm{~s}, 5 \mathrm{H}, \mathrm{Cp}), 6.21(\mathrm{~s}, 5 \mathrm{H}, \mathrm{Cp}) ;{ }^{13} \mathrm{C} \mathrm{NMR}(75 \mathrm{MHz}) \delta 13.0$ $\left(\mathrm{CH}_{3}\right), 46.3\left(\mathrm{CH}_{2}\right), 109.0(\mathrm{Cp}), 112.0(\mathrm{Cp}), 126.4(\mathrm{C}=\mathrm{C}), 142.8(\mathrm{C}=\mathrm{C}), 191.0(\mathrm{C}=\mathrm{S})$; HRMS (ESI) calcd for $\mathrm{C}_{15} \mathrm{H}_{15} \mathrm{NNaS}_{2}{ }^{48} \mathrm{Ti}^{80} \mathrm{Se}_{2}[\mathrm{M}+\mathrm{Na}]^{+}:$503.83535. Found: 503.8350. Anal. calcd for $\mathrm{C}_{15} \mathrm{H}_{15} \mathrm{NS}_{2} \mathrm{TiSe}_{2} . \mathrm{CH}_{2} \mathrm{Cl}_{2}$ : C, 34.06; H 3.04; N, 2.48. Found: C, 34.51; H 3.22; N, 3.12.

Synthesis of [NEt 4$][Z n(E t-t h i a z d s)$ 2] 5. To a dry two necked flask containing 2 (350 mg, 0.86 mmol) was added under nitrogen a freshly prepared solution of $\mathrm{NaOMe}(6.9 \mathrm{mmol})$ in dry methanol (from $157 \mathrm{mg}$ of $\mathrm{Na}$ in $10 \mathrm{~mL}$ of dry $\mathrm{MeOH}$ ). The solution was stirred 1 hour then $\mathrm{ZnCl}_{2}(58 \mathrm{mg}, 0.43 \mathrm{mmol})$ and $\mathrm{NEt}_{4} \mathrm{Br}(199 \mathrm{mg}, 0.94 \mathrm{mmol})$ were added. The reaction mixture was stirred overnight. The precipitate formed in the medium was filtered, washed with ethanol and dried to afford 5 as a yellow powder in $94 \%$ Yield; $\mathrm{Mp}=210^{\circ} \mathrm{C}(\mathrm{dec}) ;{ }^{1} \mathrm{H}$ NMR $\left(\mathrm{CD}_{3} \mathrm{CN}\right.$, $300 \mathrm{MHz}) \delta 1.19\left(\mathrm{t}, 24 \mathrm{H}, \mathrm{N}\left(\mathrm{CH}_{2} \mathrm{C}_{3}\right)_{4},{ }^{3} J=7.2 \mathrm{~Hz}\right), 1.28\left(\mathrm{t}, 6 \mathrm{H}, \mathrm{CH}_{3},{ }^{3} J=6.9 \mathrm{~Hz}\right), 3.14$ (q, $\left.16 \mathrm{H}, \mathrm{N}\left(\mathrm{C}_{2} \mathrm{CH}_{3}\right)_{4},{ }^{3} \mathrm{~J}=7.2 \mathrm{~Hz}\right), 4.44\left(\mathrm{q}, 4 \mathrm{H}, \mathrm{NCH}_{2},{ }^{3} \mathrm{~J}=6.9 \mathrm{~Hz}\right) ;{ }^{13} \mathrm{C} \mathrm{NMR}\left(\left(\mathrm{CD}_{3}\right)_{2} \mathrm{SO}\right.$ $75 \mathrm{MHz},) \delta=7.8\left(\mathrm{CH}_{3}\right), 13.2\left(\mathrm{CH}_{3}\right), 49.2\left(\mathrm{CH}_{2}\right), 53.2\left(\mathrm{CH}_{2}\right), 109.9(\mathrm{C}=\mathrm{C}), 137.7(\mathrm{C}=\mathrm{C}), 184.6$ $(\mathrm{C}=\mathrm{S})$; HRMS (ESI) calcd for $\left[\mathrm{A}^{2-}, \mathrm{C}^{+}\right]\left(\mathrm{C}_{18} \mathrm{H}_{30} \mathrm{~N}_{3} \mathrm{~S}_{4}{ }^{64} \mathrm{Zn}^{80} \mathrm{Se}_{4}\right)$ : 799.72749. Found: 799.7300 . 


\section{Synthesis of selenophene 6 from 3}

A solution of 3 (160 mg, $0.49 \mathrm{mmol})$ in $20 \mathrm{~mL}$ of toluene was refluxed overnight. The solvent was evaporated in vacuo. The concentrated solution was purified by chromatography on silica gel using $\mathrm{CH}_{2} \mathrm{Cl}_{2}$ as eluent to afford 6 as a brown powder. Crystals of sufficient quality for $\mathrm{X}$ ray diffraction were obtained by slow evaporation of $\mathrm{CH}_{2} \mathrm{Cl}_{2}$. Yield: $57 \%$ from $2 . \mathrm{Mp}=220^{\circ} \mathrm{C}$; $\mathrm{R}_{f}=0.3\left(\mathrm{SiO}_{2}, \mathrm{CH}_{2} \mathrm{Cl}_{2}\right) ;{ }^{1} \mathrm{H} \mathrm{NMR}(300 \mathrm{MHz}) \delta 1.47\left(\mathrm{t}, 6 \mathrm{H}, \mathrm{CH}_{3},{ }^{3} \mathrm{~J}=7.0 \mathrm{~Hz}\right), 4.31\left(\mathrm{q}, 4 \mathrm{H}, \mathrm{CH}_{2}\right.$, $\left.{ }^{3} J=7 \mathrm{~Hz}\right) .{ }^{13} \mathrm{C}$ NMR $(75 \mathrm{MHz}) \delta 12.2\left(\mathrm{CH}_{3}\right), 46.2\left(\mathrm{CH}_{2}\right), 114.2(\mathrm{C}=\mathrm{C}), 135.4(\mathrm{C}=\mathrm{C}), 186.9$ $(\mathrm{C}=\mathrm{S})$. HRMS (ESI) calcd for $\mathrm{C}_{10} \mathrm{H}_{10} \mathrm{~N}_{2} \mathrm{NaS}_{4}{ }^{80} \mathrm{Se}[\mathrm{M}+\mathrm{Na}]^{+}:$388.87843. Found: 388.8786. UVvis $\left(\mathrm{CH}_{2} \mathrm{Cl}_{2}\right) \quad \lambda(\mathrm{nm}) \quad\left(\varepsilon \quad\left[\mathrm{L} \cdot \mathrm{mol}^{-1} \mathrm{~cm}^{-1}\right]\right) 378$ (39640), 394 (43420); Anal. calcd for $\mathrm{C}_{10} \mathrm{H}_{10} \mathrm{~N}_{2} \mathrm{~S}_{4} \mathrm{Se} .0 .25 \mathrm{CH}_{2} \mathrm{Cl}_{2}$ : C, 31.84; H 2.74. Found: C, 31.81; H 2.77.

\section{Synthesis of Diselenine 7}

From 4 : To a solution of $4(100 \mathrm{mg}, 0.20 \mathrm{mmol})$ in $20 \mathrm{~mL}$ of $\mathrm{CH}_{2} \mathrm{Cl}_{2}$ a solution of $5 \mathrm{~mL}$ of THF containing $\mathrm{NaCl}(47 \mathrm{mg}, 0.8 \mathrm{mmol})$ and $200 \mathrm{mg}$ of $\mathrm{SiO}_{2}$ was heated at $35^{\circ} \mathrm{C}$ under inert atmosphere during 4 days.

From 5 : Crystals were prepared electrochemically using a standard $\mathrm{H}$-shaped cell $(12 \mathrm{~mL})$ with Pt electrodes. An acetonitrile suspension of [ $\left.\mathrm{NEt}_{4}\right]\left[\mathrm{Zn}(\text { Et-thiazds })_{2}\right] \mathbf{5}(10 \mathrm{mg})$ was placed in the anodic compartment, and $\mathrm{NH}_{4} \mathrm{PF}_{6}$ as supporting electrolyte $(100 \mathrm{mg})$ in both compartments. Brown crystal of 7 suitable for X-ray diffraction studies, were obtained on the anode upon application of a constant current of $1 \mu \mathrm{A}$ for 20 days. ${ }^{1} \mathrm{H}$ NMR $(300 \mathrm{MHz}) \delta 1.24\left(\mathrm{t}, 6 \mathrm{H}, \mathrm{CH}_{3}\right.$, $\left.{ }^{3} J=7.0 \mathrm{~Hz}\right), 3.72\left(\mathrm{q}, 4 \mathrm{H}, \mathrm{CH}_{2},{ }^{3} J=7.0 \mathrm{~Hz}\right)$. UV-vis $\left(\mathrm{CH}_{2} \mathrm{Cl}_{2}\right) \lambda(\mathrm{nm})\left(\varepsilon\left[\mathrm{L} \mathrm{mol}^{-1} \mathrm{~cm}^{-1}\right]\right) 229$ (16300), 352 (16270), 540 (885); HRMS (ASAP) calcd for $\mathrm{C}_{10} \mathrm{H}_{11} \mathrm{~N}_{2} \mathrm{~S}_{4}{ }^{80} \mathrm{Se}_{2}[\mathrm{M}+\mathrm{H}]^{+}$: 446.81355. Found: 446.8134.

\section{Crystallography}

Suitable crystals for X-ray difraction single crystal experiment were selected and mounted with a cryoloop on the goniometer head of a D8 VENTURE Bruker AXS diffractometer using MoKa radiation ( $\lambda=0.71073 \AA$, multilayer monochromator) for compounds 6 and 7 . The structures were solved by dual-space algorithm using the SHELXT program, ${ }^{21}$ and the refined with fullmatrix least-square methods based on $\mathrm{F}^{2}$ (SHELXL). ${ }^{22}$ All non-hydrogen atoms were refined with anisotropic atomic displacement parameters. $\mathrm{H}$ atoms were finally included in their 
calculated positions. Crystallographic data on X-ray data collection and structure refinements are given in Table 1. CCDC 2063244-2063245.

Table 1 Crystallographic data

\begin{tabular}{|c|c|c|}
\hline Compound & (6) & (7) \\
\hline Formula & $\mathrm{C}_{10} \mathrm{H}_{10} \mathrm{~N}_{2} \mathrm{~S}_{4} \mathrm{Se}$ & $\mathrm{C}_{10} \mathrm{H}_{10} \mathrm{~N}_{2} \mathrm{~S}_{4} \mathrm{Se}_{2}$ \\
\hline $\mathrm{FW}\left(\mathrm{g} \cdot \mathrm{mol}^{-1}\right)$ & 365.40 & 444.36 \\
\hline Crystal system & monoclinic & monoclinic \\
\hline Space group & $P 22_{1} / c$ & $P 21 / n$ \\
\hline$a(\AA)$ & $8.7866(11)$ & $7.9196(7)$ \\
\hline$b(\AA)$ & $12.3894(9)$ & $8.7472(7)$ \\
\hline$c(\AA)$ & $12.6125(12)$ & $20.8069(19)$ \\
\hline$\alpha\left(^{\circ}\right)$ & 90 & 90 \\
\hline$\beta\left({ }^{\circ}\right)$ & $94.728(5)$ & $99.984(3)$ \\
\hline$\gamma\left({ }^{\circ}\right)$ & 90 & 90 \\
\hline$V\left(\AA^{3}\right)$ & $1368.3(2)$ & $1419.6(2)$ \\
\hline$T(\mathrm{~K})$ & $295(2)$ & $150(2)$ \\
\hline$Z$ & 4 & 4 \\
\hline$D_{\text {calc }}\left(\mathrm{g} \cdot \mathrm{cm}^{-3}\right)$ & 1.774 & 2.087 \\
\hline$\mu\left(\mathrm{mm}^{-1}\right)$ & 3.332 & 5.779 \\
\hline Total refls. & 11626 & 13819 \\
\hline Abs. Corr . & multi-scan & multi-scan \\
\hline Uniq. refls. $\left(R_{\text {int }}\right)$ & $3133(0.0438)$ & $3262(0.0396)$ \\
\hline $\begin{array}{l}\text { Unique refls. (I } \\
>2 \sigma(I))\end{array}$ & 2490 & 2975 \\
\hline$R_{1}, w R_{2}$ & $0.0297,0.0796$ & $0.0238,0.0558$ \\
\hline$R_{1}, w R_{2}$ (all data) & $0.0440,0.0876$ & $0.0283,0.0579$ \\
\hline GoF & 1.069 & 1.026 \\
\hline
\end{tabular}




\section{Theoretical Modeling}

Electrostatic Surface Potential calculations were carried out on the optimized geometry of the molecules (with Density Functional Theory using the Gaussian 09 Revision D.01 software, the B3LYP functional and the 6-31+G** basis set for all atoms. GaussView 5.0.9 was used to generate the figures.

\section{Conflict of interest}

There are no conflicts to declare.

\section{Acknowledgements}

This work was granted access to the HPC resources of CINES under the allocation 2020A0080805032 made by GENCI.

\section{References}

${ }^{1}$ G. Zhang, J. Zhao, P.C.Y. Chow, K. Jiang, J. Zhang, Z. Zhu, J. Zhang, F. Huang and H. Yan, Chem. Rev., 2018, 118, 3447-3507.

2 J. T. E. Quinn, J. Zhu, X. Li, J. Wang and Y. Li, J. Mater. Chem. C, 2017, 5, 8654-8681.

${ }^{3}$ Y. Le Gal, N. Bellec, F. Barriere, R. Clerac, M. Fourmigue, V. Dorcet, T. Roisnel and D. Lorcy, Dalton Trans., 2013, 42, 16672-16679.

${ }^{4}$ A. Filatre-Furcate, T. Higashino, D. Lorcy and T. Mori, J. Mater. Chem. C, 2015, 3, 35693573.

${ }^{5}$ K. Ijima, Y. Le Gal, T. Higashino, D. Lorcy and T. Mori, J. Mater. Chem. C, 2017, 5, 91219127.

${ }^{6}$ G. Yzambart, N. Bellec, G. Nasser, O. Jeannin, T. Roisnel, M. Fourmigué, P. Auban-Senzier, J. Íñiguez, E. Canadell and D. Lorcy, J. Am. Chem. Soc., 2012, 134,17138-17148.

7 (a) A. Krief, L. Hevesi, Organoselenium Chemistry I. Functional Group Transformations., Springer, Berlin, 1988; (b) S. Patai, Z. Rappoport (Eds.), The Chemistry of Organic Selenium and Tellurium Compounds, John. Wiley and Sons, Chichester, Vol. 1, 1986 
${ }^{8}$ Y. Le Gal, D. Ameline, N. Bellec, A. Vacher, T. Roisnel, V. Dorcet, O. Jeannin and D. Lorcy, Org. Biomol. Chem., 2015, 13, 8479-8486.

${ }^{9}$ Y. Le Gal, D. Ameline, A. Vacher, T. Roisnel, V. Dorcet and D. Lorcy, New J. Chem., 2016, 40, 9930-9935.

10 (a) C. P. Galloway, D. D. Doxsee, D. Fenske and T. B. Rauchfuss, Inorg. Chem., 1994, 33, 4537-4544; (b) J. H. Chou, T. B. Rauchfuss and L. Szczepura, J. Am. Chem. Soc., 1998, 120, 1805-1811.

${ }^{11}$ Y. Le Gal, M. Rajkumar, A. Vacher, V. Dorcet, T. Roisnel, M. Fourmigué, F. Barrière, T. Guizouarn and D. Lorcy, CrystEngComm, 2016, 18, 3925-3933.

${ }^{12}$ A. Orahovatz, M. I. Levinson, P. J. Carroll, M. V. Lakshmikantham and M. P. Cava, J. Org. Chem., 1985, 50, 1550-1552.

${ }^{13}$ W. Schroth, S. Dunger, F. Billig, R. Spitzner, R. Herzschuh, A. Vogt, T. Jende, G. Israel, J. Barche and D. Strohl, Tetrahedron, 1996, 52, 12677-12698.

${ }^{14}$ S. Ryo, D. Yoo, K. Iijima, R. Sato, Y. Le Gal, D. Lorcy and T. Mori, New J. Chem., 2019, 43, 11865-11870.

15 (a) T. Okamoto, K. Kudoh, A. Wakamiya and S. Yamaguchi, Org. Lett., 2005, 7, 5301-5304.

(b) W. Xu, L. Wu, M. Fang, Z. Ma, Z. Shan, C. Li and H. Wang, J. Org. Chem., 2017, 82, 11192-11197. (c) W. Xu, M. Wang, Z. Ma, Z. Shan, C. Li and H. Wang, J. Org. Chem., 2018, 83, 12154-12163.

16 (a) S. Murata, T. Suzuki, A. Yanagisawa and S. Suga, J. Heterocycl. Chem., 1991, 28, 433438; (b) M. R. Bryce, A. Chesney, A. K. Lay, A. S. Batsanov and J. A. K. Howard, J. Chem. Soc., Perkin Trans. 1, 1996 2451-2459.

${ }^{17}$ M. Fourmigué and A. Dhaka, Coord. Chem Rev., 2020, 403, 213084.

${ }^{18}$ R. Shukla, A. Dhaka, E. Aubert, V.Vijayakumar-Syamala, O. Jeannin, M. Fourmigué and E. Espinosa, Cryst. Growth Des., 2020, 20, 7704-7725.

${ }^{19}$ G. Cavallo, P. Metrangolo, T. Pilatti, G. Renati and G. Terraneo, Cryst. Growth Des., 2014, 14, 2697-2702.

${ }^{20}$ C. Figliola, L. Male, P. N. Horton, M. B. Pitak, S. J. Coles, S. L. Horswell and R. S. Grainger Organometallics, 2014, 33, 17, 4449-4460.

${ }^{21}$ G. M. Sheldrick, Acta Cryst. 2015, A71, 3-8.

${ }^{22}$ G. M. Sheldrick, Acta Cryst. 2015, C71, 3-8 
